\title{
EFEKTIFITAS SENAM DENGAN MODUL DALAM MENGURANGI DISMENORE PADA REMAJA SMA DI KOTA SURAKARTA
}

\author{
Yuyun Setyorini, Satino \\ Kementerian Kesehatan Politeknik Kesehatan Surakarta Jurusan Keperawatan
}

\begin{abstract}
Dysmenorrhea, Adolescents, Reproductive Health Module. Dysmenorrhea is the most common gynecological problems experienced by women. Based on the research background mentioned above, can be formulated research question "Are gymnastics with reproductive health module is effective in reducing dysmenorrhea in adolescents with dysmenorrhea in Surakarta?". While the purpose of the study was to determine the effectiveness of the exercise with the reproductive health module in reducing dysmenorrhea in adolescent high school in Surakarta. This research is a quantitative research with quasi-experimental designs and designs were used pretest posttest design. In the design of this group of teenagers are trained gymnastics dysmenorrhea with the use of reproductive health module. Where the research is in the area of Surakarta. While the research time in March to August 2015. In this study, using the chi square test. The results showed $p$ value $=0.000(p<0.05)$, which means that there is a significant effect on pain intensity between before and had performed the action. Advice for health workers to provide health education on reproductive health for young women as early as possible and further research to investigate specifically related to reproductive health in adolescents.
\end{abstract}

Keywords: Dysmenorrhea, Adolescents, Reproductive Health Module

\begin{abstract}
Abstrak: Dismenore, Remaja, Modul Kesehatan Reproduksi. Dismenore merupakan masalah ginekologis yang paling umum dialami oleh wanita. Berdasarkan latar belakang penelitian tersebut di atas, dapat dirumuskan masalah penelitian "Apakah senam dengan modul kesehatan reproduksi efektif dalam mengurangi dismenore pada remaja dengan dismenore di Kota Surakarta?". Sedangkan tujuan penelitian adalah untuk mengetahui keefektifan senam dengan modul kesehatan reproduksi dalam mengurangi dismenore pada remaja SMA di Kota Surakarta. Penelitian ini merupakan penelitian kuantitatif dengan desain quasi eksperimen dan rancangan yang digunakan pretest posttest design. Pada rancangan ini sekelompok remaja dilatih senam dismenore dengan penggunaan modul kesehatan reproduksi. Tempat penelitian adalah di wilayah Kota Surakarta. Sedangkan waktu penelitian pada Bulan Maret sampai dengan Agustus 2015. Pada penelitian ini menggunakan uji chi square. Hasil penelitian menunjukkan nilai $\mathrm{p}$ value $=0.000(\mathrm{p}<0.05)$ yang berarti bahwa terdapat pengaruh yang signifikan terhadap intensitas nyeri antara sebelum dan sudah dilakukan tindakan. Saran bagi petugas kesehatan untuk dapat memberikan pendidikan kesehatan tentang kesehatan reproduksi bagi remaja putri sedini mungkin dan peneliti selanjutnya untuk meneliti terkait kesehatan reproduksi khususnya pada remaja.
\end{abstract}

Kata Kunci: Dismenore, Remaja, Modul Kesehatan Reproduksi 


\section{PENDAHULUAN}

Masa remaja merupakan suatu fase perkembangan yang dinamis dalam siklus kehidupan seseorang. Masa remaja adalah masa transisi dari masa anak-anak ke masa dewasa yang ditandai dengan percepatan perkembangan fisik, mental, emosional, dan sosial (Monks, Koers, Haditomo, 2002). Masa remaja merupakan suatu periode dalam rentang kehidupan manusia dan terjadi peralihan dari masa kana-kanak ke masa dewasa. Masa remaja merupakan suatu fase perkembangan yang dinamis dalam kehidupan seseorang. Masa ini ditandai dengan percepatan perkembangan fisik, kognitif, sosial dan emosional. Perubahan paling awal yaitu perkembangan secara fisik yaitu mulai mengalami menstruasi. Menstruasi dimulai saat pubertas dan kemampuan seorang wanita untuk bereproduksi (Wong, et al, 2009).

Menstruasi yang dialami oleh wanita merupakan sesuatu yang fisiologis atau normal. Dismenore dapat menimbulkan dampak pada aktivitas atau kegiatan sehari-hari, terutama pada remaja. Dismenore dapat membuat wanita tidak bisa beraktivitas secara normal dan memerlukan obat (Prawirohardjo, 2005). Dismenore yang mengganggu aktivitas dapat menurunkan kualitas hidup wanita. Dismenore dapat menyebabkan seorang remaja tidak dapat berkonsentrasi dalam belajar dan motivasi belajar menurun karena nyeri yang dirasakan. Menurut Nathan (2005), menyatakan bahwa 30$60 \%$ wanita mengalami dismenore, dan 7$15 \%$ tidak dapat pergi ke sekolah atau bekerja.

Menurut Woo dan Mc Eneaney (2010), dismenore mempengaruhi kualitas hidup sebesar 40-90\% wanita, dimana satu dari tiga belas wanita yang mengalami dismenore tidak hadir bekerja dan sekolah selama 1-3 hari perbulan. Untuk mengatasi kondisi seperti ini dapat dilakukan dengan terapi farmakologi dan non farmakologi. Terapi non farmakologi lebih banyak dipilih karena lebih aman bila dibandingkan dengan terapi farmakologi. Terapi non farmakologi menurut Bobak, et al, 2005) untuk mengatasi dismenore dapat dilakukan dengan cara kompres hangat, mandi air hangat, massase, distraksi, latihan fisik/ exercise, tidur atau istirahat yang cukup, diet rendah garam dan peningkatan penggunaan diuretik alami seperti daun seledri.

Dismenore atau nyeri menstruasi merupakan gejala yang paling sering dikeluhkan oleh wanita usia reproduktif. Nyeri atau rasa sakit yang siklik bersamaan dengan menstruasi ini sering dirasakan seperti rasa kram pada perut dan dapat disertai dengan rasa sakit yang menjalar ke punggung, dengan rasa mual dan muntah, sakit kepala ataupun diare. Salah satu latihan untuk menurunkan nyeri saat menstruasi atau dismenore adalah dengan melakukan abdominal stretching exercise (Thermacare, 2010). Tujuan penelitian ini adalah untuk mengetahui keefektifan senam dengan modul kesehatan reproduksi dalam mengurangi dismenore pada remaja SMA di Kota Surakarta.

\section{METODE PENELITIAN}

Penelitian ini merupakan penelitian kuantitatif dengan desain quasi eksperimen dan rancangan yang digunakan pretest posttest control group design (Sugiono, 2009; Notoatmodjo, 2010). Tempat penelitian adalah di wilayah Kota Surakarta. Sedangkan waktu penelitian pada Bulan Maret sampai 
dengan Agustus 2015. Populasi pada penelitian ini adalah remaja putri yang mengalami dismenore yang masih bersekolah (SMA) di Kota Surakarta. Teknik pengambilan sampel pada penelitian ini menggunakan non probability sampling yaitu teknik consecutive sampling.

Teknik consecutive sampling ini dilakukan dengan cara setiap responden yang memenuhi kriteria penelitian dimasukkan dalam penelitian sampai jumlah sampel yang dibutuhkan terpenuhi pada kurun waktu tertentu. Variabel dependent dalam penelitian ini adalah dismenore. Sedangkan variabel independen dalam penelitian ini adalah modul kesehatan reproduksi. Instrumen yang digunakan pada penelitian ini adalah instrumen yang sudah dipatenkan sehingga tidak perlu dilakukan uji validitas dan reliabilitas. Uji statistic yang digunakan yaitu uji chi square.

\section{HASIL PENELITIAN}

Karakteristik responden berdasarkan usia terbanyak adalah usia remaja antara 14-16 tahun yaitu sebesar 63.33\% sedangkan responden yang berusia 17-19 tahun sebanyak $36.67 \%$.

Karakteristik responden berdasarkan kelas adalah sebagai berikut: $56.67 \%$ responden berada pada kelas $\mathrm{X}$ dan $43.33 \%$ responden adalah kelas XI.

Responden yang mengalami dismenore terbagi menjadi dua yaitu nyeri berat dan ringan. Responden dengan nyeri berat pada pengukuran pre tindakan sebanyak $93.33 \%$ sedangkan yang merasakan nyeri ringan sebanyak $6.67 \%$.

Pada pengukuran intensitas nyeri setelah dilakukan tindakan didapatkan data bahwa responden dengan nyeri ringan sebesar $73.33 \%$ sedangkan responden dengan nyeri berat sebesar $26.67 \%$.

Hasil uji statistik dengan chisquare didapatkan bahwa nilai $\mathrm{p}$ value $=$ $0.000(\mathrm{p}<0.05)$ yang berarti ada perbedaan yang bermakna intensitas nyeri setelah dilakukan tindakan senam dismenore dan penggunaan modul kesehatan reproduksi pada remaja SMA.

Berdasarkan hasil uji chi-square didapatkan bahwa nilai $\mathrm{p}$ value $=0.000$ $(\mathrm{p}<0.05)$, hal ini menunjukkan bahwa terdapat perbedaan yang signifikan antara intensitas nyeri sebelum dengan sesudah dilakukan tindakan senam dismenore dan penggunaan modul kesehatan reproduksi. Senam dismenore merupakan salah satu penatalaksanaan secara non farmakologi yang aman diterapkan karena menggunakan proses fisiologis. Menurut Woo \& McEneaney (2010) dan Nathan (2005) menyatakan bahwa salah satu cara untuk meredakan dismenore adalah dengan melakukan senam atau latihan. Demikian juga menurut Daley (2008) bahwa latihan yang efektif dapat menurunkan nyeri haid (dismenore primer).

\section{PEMBAHASAN}

Hasil penelitian ini juga didukung oleh Harry (2007), yaitu dengan melakukan exercise maka tubuh akan menghasilkan endorphin. Endorphin berfungsi sebagai obat penenang alami, dan dapat menimbulkan rasa nyaman, sehingga dapat menurunkan rasa nyeri yang dirasakan. Latihan atau exercise dapat meningkatkan kadar endorphin empat sampai lima kali. Pada saat exercise dilakukan, maka endorphin akan keluar dan ditangkap oleh reseptor di hipothalamus dan sistem limbik yang mempunyai fungsi mengatur emosi. 
Menurut Harry (2007), dengan adanya peningkatan endorphin didalam darah maka akan terjadi penurunan rasa nyeri, peningjatan daya ingat, memperbaiki nafsu makan, kemampuan seksual, tekanan darah dan pernafasan.

Menurut Jhamb, et al. (2008) latihan fisik memiliki hubungan yang signifikan dengan penurunan tingkat keletihan otot. Remaja dengan dismenore akan mengalami kram terutama pada abdomen bawah yang bersifat siklik disebabkan karena kontraksi yang kuat dan lama pada dinding uterus sehingga terjadi kelelahan otot dan physical inactivity maka diperlukan exercise untuk menghilangkan kram tersebut.

Remaja dengan dismenore akan mengalami kontraksi uterus yang siklik sehingga dapat menyebabkan terjadinya kelelahan otot dan lemahnya aktivitas fisik, sehingga sangat diperlukan adanya latihan untuk menghilangkan kram otot. Menurut Thermacare (2010), Salah satu cara untuk mengurangi intensitas nyeri pada saat menstruasi adalah latihan abdominal stretching exercise. Latihan ini dilakukan pada saat dismenore untuk meningkatkan kekuatan otot, daya tahan dan fleksibilitas otot.

Latihan abdominal stretching exercise ini juga dapat meningkatkan kebugaran, mengoptimalkan daya ingat, meningkatkan mental dan relaksasi fisik, meningkatkan perkembangan kesadaran tubuh, mengurangi ketegangan otot dan nyeri otot, serta mengurangi rasa sakit pada saat menstruasi. Abdominal stretching exercise merupakan suatu latihan peregangan otot terutama pada bagian perut yang dilakukan selama 10 menit. Latihan-latihan ini dirancang untuk meningkatkan kekuatan otot, daya tahan dan fleksibilitas otot, sehingga diharapkan dapat menurunkan nyeri menstruasi atau dismenore. Abdominal stretching exercise merupakan gabungan dari enam latihan yang terdiri cat stretch, lower trunk rotation, hip stretch, abdominal strengthening (curl up), lower abdominal strengthening dan the bridge position.

Stretching (peregangan) adalah aktivitas fisik yang sederhana. Manfaat stretching menurut Alter (2008) adalah dapat meningkatkan kebugaran, mengoptimalkan daya tangkap, meningkatkan mental dan relaksasi fisik, meningkatkan perkembangan kesadaran tubuh, mengurangi ketegangan otot (kram), mengurangi nyeri otot dan mengurangi rasa sakit pada saat menstruasi (dismenore). Sedang-kan menurut Anderson (2010) manfaat melakukan stretching adalah mengurangi ketegangan otot, memperbaiki peredaran darah, mengurangi kecemasan, perasaan tertekan, dan kelelahan, memper-baiki kewaspadaan mental, mengurangi risiko cedera, memper-mudah pekerjaan, memadukan pikiran ke dalam tubuh serta membuat perasaan lebih baik.

\section{KESIMPULAN DAN SARAN}

Kesimpulan yang dapat ditarik dari hasil penelitian dengan judul efektifitas modul kesehatan reproduksi dalam mengurangi dismenore pada remaja SMA di wilayah Kota Surakarta adalah sebagai berikut:

1. Usia responden terbanyak pada rentang 14-16 tahun sebesar $63.33 \%$, sedangkan usia 17-19 tahun sebesar $36.67 \%$.

2. Karakteristik responden berdasarkan kelas di bagi menjadi dua kelas yaitu kelas $\mathrm{X}$ dengan $56.67 \%$ dan kelas XI dengan $43.33 \%$. 
3. Intensitas nyeri responden sebelum dilakukan tindakan terbanyak pada nyeri berat yaitu $93.33 \%$ sedangkan nyeri ringan $6.67 \%$.

4. Intensitas nyeri responden setelah dilakukan tindakan senam dismenore dengan penggunaan modul kesehatan reproduksi didapatkan hasil nyeri ringan $73.33 \%$ dan nyeri berat $26.67 \%$.

5. Tindakan senam dismenore dengan modul kesehatan reproduksi efektif digunakan dalam mengurangi nyeri pada saat menstruasi (dismenore) pada remaja SMA di wilayah Kota Surakarta dengan nilai $\mathrm{p}$ value $=$ 0.000 ( $\mathrm{p}<0,05)$.

Berdasarkan hasil penelitian ini saran yang dapat diberikan adalah bagi petugas kesehatan untuk dapat memberikan pendidikan kesehatan khususnya tentang kesehatan reproduksi bagi remaja putri sedini mungkin dan kepada peneliti selanjutnya untuk meneliti terkait kesehatan reproduksi khususnya pada remaja, karena masa remaja merupakan masa transisi dan perlu adanya pendampingan.

\section{DAFTAR RUJUKAN}

Bobak, I.M., et.al. (2005). Maternity Nursing. Fourth Edition. Mosby Year Book, Inc.
Harry (2007). Mekanisme endorphin dalam tubuh. Dari http://klikharry.files. wordpres.com 9 Januari 2013.

Nathan, A. (2005). Primary dysmenorrhoea, practice nurse minor ailments. Dari http://proquest.umi.com/pqdweb?i ndex=65 9 Januari 2013.

Prawirohardjo, S. (2005). Ilmu Kebidanan. Jakarta: Yayasan Bina Pustaka Sarwono Prawirohardjo.

Thermacare (2010). Abdominal stretching exercises for menstrual pain. Dari http://www.chiromax.com/media/a bstretch.pdf 9 Januari 2013.

Wong, D.L., Perry, S.E., \& Hockenberry, M.J. (2002). Maternal child nursing care. Mosby: St. Louis.

Wong, Algreen, Arnow (2003). Nursing care of infants and children. Canada: Mosby Elsivier.

Wong, D.L., et.al. (2009). Wong's essentials of pediatric nursing. St. Louis, Missouri: Mosby.

Woo, P. \& Mc Eneaney, M.J. (2010). New strategies to treat primary dysmenorrhea. The clinical advisor. Dari http://proquest. umi.com/pqdweb?index $=6$ Januari 2013 